\title{
Marek Wojnar
}

Uniwersytet Jagielloński

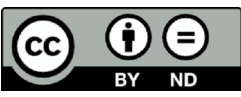

\section{Dmytro Doncow i Polska - dwa mity}

Zarys treści: Tekst stanowi próbę spojrzenia na stosunek najważniejszego ideologa ukraińskiego nacjonalizmu integralnego Dmytra Doncowa wobec Polski w oparciu o opracowanie źródła reprezentatywnego dla tej problematyki. Doncow ostrzega ukraińską społeczność przed orientacją na Polskę wobec wzrostu wpływów rosyjskich nad Wisłą oraz słabnięciem tam ducha tzw. wojowniczego zachodu.

Summary: The article is the edition of the source text „Is it West?” by Dmytro Dontsov, which was published in the Lviv „Vistnyk” in May 1934. The paper refers to the Ukrainian nationalist ideologist's attitude to the nationalism towards Poland. However, on the one hand the article contradicts common opinions of the author Polophilia, but on the other, indicates that for the main enemy Dontsov considered Russia.

Słowa kluczowe: integralny nacjonalizm, Dmytro Doncow, Polska, Rosja, Ukraina.

Keywords: integral nationalism, Dmytro Dontsov, Poland, Russia, Ukraine.

Dmytro Doncow (1883-1973), najbardziej znany ideolog ukraińskiego nacjonalizmu, jest postacią złożoną. Ukraiński myśliciel w swoim rozwoju intelektualnym przebył długą drogę, poczynając od fascynacji ideologią marksistowską, przez przejście na pozycje nacjonalizmu integralnego w latach dwudziestych, coraz mocniejsze uleganie wpływom faszystowskim w następnej dekadzie, aż po opowiedzenie się po stronie konserwatyzmu w latach II wojny światowej i później ${ }^{1}$. Myśl Doncowa uznawana jest przez badaczy przedmiotu za jeden z głównych nurtów ukraińskiego nacjonalizmu integralnego, tzw. czynny nacjonalizm. Zdecydowanie więcej sporów budzi określanie jego ideologii jako faszystowskiej².

1 T. Stryjek, Europejskość Dmytra Doncowa, czyli o cechach szczególnych ideologii ukraińskiego nacjonalizmu [w:] Antypolska akcja OUN-UPA 1943-1944. Fakty i interpretacje, red. G. Motyka, D. Libionka, Warszawa 2002, s. 20.

2 Iwan Łysiak Rudnicki przekonywał, że ukraiński nacjonalizm (obejmujący również Doncowa) należy porównywać nie z faszyzmem, ale z radykalnymi ruchami narodowymi narodów rolniczych 
Punktem wyjścia dla doktryny Doncowa w okresie międzywojennym było radykalne zerwanie ze zdecydowaną większością tradycji intelektualnej ukraińskiej myśli przedrewolucyjnej, którą ukraiński myśliciel określił sam mianem prowansalstwa. Spośród wszystkich intelektualistów poprzedniego okresu Doncow wystawiał pozytywną ocenę w zasadzie wyłącznie Tarasowi Szewczence i Łesi Ukraińce. Z kolei głoszone przez Mychajłę Hruszewskiego czy Mychajłę Drahomanowa idee racjonalizmu i humanizmu Doncow zastąpił woluntaryzmem i egoizmem narodowym. Woluntaryzm Doncowa stanowił niejako syntezę „woli do życia” Schopenhauera i „woli do władzy” Nietschego, z tym, że w odróżnieniu od nich Docnow przyporządkowywał te pojęcia nacji jako kolektywnej osobie. Za rozumianym w taki sposób woluntaryzmem szło rozumienie stosunków pomiędzy narodami na gruncie darwinistycznym oraz interpretacja pojęcia narodu w duchu aksjomatycznym. Doncow rozpatrywał nację jako naturalną wspólnotę przypominającą gatunek przyrodniczy (species). Nie trzeba dodawać, że nacje znajdowały się w stanie permanentnego współzawodnictwa, przez co biologistyczna rywalizacja pomiędzy nimi prowadzić miała do postępu ${ }^{3}$. Organiczność nacji przejawiała się w niemożności subiektywnego wyboru wspólnoty, do której przynależy jednostka. Nacja posiadała charakter wszechogarniający, a jej prawa według Doncowa stały wyżej, aniżeli prawa jednostki czy wspólnoty ogólnoludzkiej.

Wśród wymienionych przez Doncowa wymagań „czynnego nacjonalizmu” należy wyszczególnić:
a. woluntaryzm (antyintelektualizm)
b. wojowniczość (antypacyfizm)
c. romantyzm, dogmatyzm i iluzjonizm
d. fanatyzm i ,amoralność”
e. syntezę nacjonalizmu i internacjonalizmu
f. twórczą przemoc i inicjatywną mniejszość 4 .

Powyższe idee wyłożył Doncow w wydanej w 1926 r. we Lwowie pracy Nacjonalizm. Uzupełnienie dla zaprezentowanej w niej ideologii czynnego nacjonalizmu stanowi

w rodzaju rumuńskiej Żelaznej Gwardii, chorwackich ustaszy, słowackich hlinkowców czy polskiego ONR. Ołeksandr Zajcew uważa, że ideologię Doncowa do 1939 r. należy rozpatrywać jako protofaszyzm, chociaż zasadniczo idee autora Nacjonalizmu znajdują się bliżej nurtu zwanego konserwatywną rewolucją. Tomasz Stryjek w bardziej zdecydowany sposób skłania się ku określeniu Doncowa jako zwolennika faszyzmu, zaznaczając przy tym, iż był to faszyzm środkowo czy też wschodnioeuropejski. I. Лисяк Рудницкий, Історичні есе, t. 2, Київ 1994, s. 251-252; О. Зайцев, Український інтегральний націоналізм (1920-1930-ті роки). Нариси інтелектуальної історії, Київ 2013, s. 237; T. Stryjek, op. cit., s. 20-21. Zdecydowanie chętniej myśl Doncowa zaliczana jest do myśli faszystowskiej przez jego radykalnych przeciwników z Wiktorem Poliszczukiem na czele, por. W. Poliszczuk, Doktryna Dmytra Doncowa. Tekst. Analiza, Toronto 2006, s. 310.

3 Por. О. Зайцев, op. cit., s. 174; T. Stryjek, Ukraińska idea narodowa okresu międzywojennego, Toruń 2013 (wydanie drugie), s. 138-140.

4 О. Зайцев, оp. cit., s. 183-184. 
publicystyka Doncowa ukazująca się na łamach lwowskich periodyków „Zahrawa. Orhan Nezałeżnoj Dumky”, „Literaturo-Nauakowy Wistynyk” czy wreszcie „Wistnyk”. $\mathrm{W}$ jego tekstach publikowanych w tych czasopismach możemy zobaczyć, w jaki sposób ideologia „czynnego nacjonalizmu” mogła znajdować zastosowanie w sprawach bieżących. Jednocześnie niektóre $\mathrm{z}$ artykułów zdają się świadczyć o nowych tendencjach w myśli ukraińskiego ideologa. Przykładem tego może być np. rozwinięcie teorii inicjatywnej mniejszości w koncepcję „zakonu”. Oprócz tego wraz z przemianami politycznymi zachodzącymi w latach trzydziestych w tekstach ukraińskiego myśliciela pojawia się coraz więcej elementów zaczerpniętych z włoskiego faszyzmu i niemieckiego nazizmu ${ }^{6}$.

Jednocześnie na zarysowany powyżej model teoretyczny Doncow nakładał kolektywny ideał ukraińskiej nacji rozumianej jako „najdalsza peryferia okcydentu”. Ideał ten prowadzący do pełnej separacji Ukrainy od Rosji po raz pierwszy można dostrzec już w pracy Moderne Moskwofilstwo (początkowo w aspekcie kulturalnym) ${ }^{7}$ i nie zważając na wszelakie przemiany, w myśli Doncowa pozostał jego elementem stałym $^{8}$. Przyjęcie radykalnie antyrosyjskiej pozycji przez ukraińskiego myśliciela musiało rzutować również na jego stosunek wobec Polski, prowadząc do jego pewnej marginalizacji. Niemniej późniejsze wydarzenia II wojny światowej, z rzezią wołyńsko-galicyjską na czele, przyczyniły się do wytworzenia w publicznym (w tym również w naukowym) dyskursie zupełnie odmiennego obrazu stosunku Doncowa wobec Polski. Zgodnie z nim ideologia wytworzona przez Doncowa miała przyczynić się do wykreowania wśród młodszego pokolenia Ukraińców atmosfery, w której możliwa była wpierw rozprawa z Żydami, a następnie z Polakami ${ }^{9}$. Pomimo pewnych racji zwolenników takiego poglądu, tworzenie bezpośredniego związku przyczynowo-skutkowego pomiędzy myślą Doncowa a zbrodniami na Wołyniu wywołuje wiele wątpliwości. Najważniejszą spośród nich w omawianym temacie jest ta, że taka interpretacja automatycznie prowadzi do zaklasyfikowania Doncowa jako myśliciela jednoznacznie antypolskiego.

Na nieadekwatność takiego postrzegania postaci Doncowa zwracali uwagę liczni badacze polscy i ukraińscy biorący udział w polskim dyskursie publicznym i naukowym. Podkreślali oni polonofilskie elementy w myśli Doncowa oraz zaznaczali, iż postawa autora Nacjonalizmu była raczej antyhumanistyczna, aniżeli antypolska, popadając czasami przy tym w pewną idealizację tego zagadnienia. Jeszcze

5 Por. Д. Донцов, Партія чи орден „Вістник” 1933, nr 2, s. 116-127.

6 Por. T. Stryjek, Ukraińska idea narodowa..., s. 149-156.

7 Д. Донцов, Модерне москвофільство, Київ 1913, s. 30.

8 Bezpośrednio zostało to wyrażone w pracy Pidstawy naszoj polityky, w której Doncow opisuje owe podstawy polityki ukraińskiej w następujący sposób „w polityce wewnętrznej - pielęgnowanie wszystkich zasad kultury zachodniej, jakie ratują Europę (i nas) od moskiewskiej plagi, 2. w polityce zagranicznej - pełna separacja od Rosji. I tam i tu ścisły związek z Europą", idem, Пiдстави нашої політики, Відень 1921, s. 77.

9 R. Ziemkiewicz, Myśmy wszystko zapomnieli, http://www.rp.pl/artykul/125944.html [dostęp 26.04.2014]; L. Kulińska, Działalność terrorystyczna i sabotażowa ukraińskich organizacji nacjonalistycznych w Polsce w latach 1922-1939, Kraków 2009, s. 56. W. Poliszczuk, op. cit., s. 311. 
na emigracji w Paryżu Jerzy Łobodowski w redagowanych przez Jerzego Giedroyca "Zeszytach Historycznych" wskazywał na polonofilskie aspekty ideologii Doncowa ${ }^{10}$. Grzegorz Motyka w pracy Ukraińska partyzantka 1942-1960 zauważa, że w aspekcie geopolitycznym Doncow traktował Polskę jako potencjalnego sojusznika Ukrainy w konflikcie z Rosją, lecz ta myśl nie została zauważona przez młode pokolenie ukraińskie, które większą wagę przywiązywało do kwestii filozoficznych ${ }^{11}$. Na podobne aspekty w myśli Doncowa zwracał wcześniej uwagę również Ryszard Torzecki ${ }^{12}$. Nie inaczej interpretował idee Doncowa Roman Wysocki w pracy Organizacja Ukraińskich Nacjonalistów w Polsce w latach 1929-1939, uznając Pidstawy naszoji polityky za wyraz „polonofilskich przekonań Doncowa”"13. Jeszcze dalej poszedł w ocenie znany ukraiński publicysta Bohdan Osadczuk, który w rozmowie z Basilem Kerskim i Andrzejem Stanisławem Kowalczykiem podkreśla: „Doncow nigdy nie napisał ani jednego antypolskiego zdania. Stale się bał, że Polacy odbiorą mu azyl. Na tym polegało całe nieszczęście"14.

Z bardziej zniuansowaną oceną możemy się spotkać w pracy Tomasza Stryjka Ukraińska idea narodowa okresu międzywojennego, który zauważa ewolucję poglądów Doncowa w stosunku do Polski, a za datę przełomową w odejściu od stanowiska przychylnego w kierunku negatywnego uznaje rok 1934, zwracając uwagę na znaczenie wydanego wówczas tekstu Czy Zachid ${ }^{15}$. Najpełniejszy i zarazem najbardziej wyważony opis obrazu Polski w pisarstwie Doncowa przedstawił wyżej wspomniany Roman Wysocki w artykule Źródło twórczej inspiracji czy wróg? Obraz Polski i stosunków polsko-ukraińskich w ujęciu Dmytra Doncowa? ${ }^{16}$. Jednocześnie wydaje się, że dalsze podejmowanie tej problematyki jest ze wszech miar zasadne, gdyż te nieliczne rzetelne opracowania zagadnienia póki co nie przyczyniły się do radykalnej redefinicji dwóch uproszczonych opinii na temat stosunku Doncowa wobec Polski ${ }^{17}$.

Pierwsze kontakty Doncowa z Polakami i kulturą polską przypadają na początek XX w. Jeszcze studiując na Uniwersytecie Petersburskim, młody myśliciel

10 J. Łobodowski, Dmytro Doncow. Życie i działalność, „Zeszyty Historyczne”, 1981, z. 55, nr 158-159.

11 G. Motyka, Ukrainska partyzantka 1942-1960. Działalność Organizacji Ukraińskich Nacjonalistów i Ukraińskiej Powstańczej Armii, Warszawa 2006, s. 44.

12 R. Torzecki, Kwestia ukraińska w Polsce w latach 1923-1929, Kraków 1989, s. 49 i 161.

13 R. Wysocki, Organizacja Ukraińskich Nacjonalistów w Polsce w latach 1929-1939, Lublin 2003, s. 83.

14 Polska i Ukraina: rozmowy z Bohdanem Osadczukiem przeprowadzili B. Kerski i A. S. Kowalczyk, Wrocław 2008, s. 32-33.

15 T. Stryjek, Ukrainska idea narodowa..., s. 153.

16 R. Wysocki, Źródło twórczej inspiracji czy wróg? Obraz Polski i stosunków polsko-ukraińskich w ujęciu Dmytra Doncowa, [w:] Primum vivere deinde philosophari. O ludziach czynu w dziejach Europy Środkowej i Wschodniej. Księga jubileuszowa dedykowana Profesorowi Janowi Rzońcy z okazji siedemdziesiątych urodzin, red. M. Białokur, A. Szczepaniak, Opole-Toruń 2009, s. 203-217.

17 Pomimo dużej wartości naukowej powyżej cytowanego tekstu (autor wykorzystał m.in. materiały dotyczące Doncowa z archiwów kanadyjskich), skala jego oddziaływania w porównaniu z pracami Wiktora Poliszczuka jest niestety marginalna. 
zaczytywał się w utworach Stanisława Przybyszewskiego. W 1907 r. Doncow miał okazję przyglądać się działalności polskich posłów pracujących w petersburskiej Dumie państwowej, a rok później podczas wyjazdu dla poratowania zdrowia do Zakopanego zetknął się bezpośrednio z polską inteligencją. Wówczas poznał Stanisława Brzozowskiego, znajomość z którym miała na niego szczególnie znaczący wpływ. W 1911 r., będąc stałym korespondentem moskiewskiego dziennika „Utro Rosiji”, opisywał stosunki polsko-ukraińskie w Galicji, krytykując przy tym środowiska narodowo-demokratyczne i konserwatywne ${ }^{18}$. Jednocześnie już wówczas deklarował sens współpracy z tymi środowiskami polskimi, które deklarowały swoją antyrosyjskość.

W 1915 r. Doncow wydał pracę Gross Polen und die Zenträlmachte, w której to przekonywał, iż brak pretensji państw centralnych wobec wschodu Europy nie powinien pociągać za sobą dobrowolności w rozwiązaniu kwestii polskiej ${ }^{19}$. Rok później w publicystyce Doncowa po raz pierwszy pojawia się koncepcja ,jednego kolosalnego wału obronnego przeciwko Rosji od Morza Północnego do Śródziemnego"20. Założenie to sprawiło, iż Doncow w coraz większym stopniu dostrzegał konieczność porozumienia z Polakami.

Pełny wyraz tego dał w pracy Pidstawy naszoji polityky (Wiedeń 1921), w której wzywał Ukraińców do budowy wraz z Polską, Rumunią i Węgrami silnego bloku państw środkowoeuropejskich będącego w stanie oprzeć się imperializmowi rosyjskiemu. Ukraińców sceptycznych wobec porozumienia z Polakami, którzy stanowili bez wątpienia większość w Galicji Wschodniej, określał mianem „maniaków, którym miłe są tradycje Targowicy i Perejasławia"21. Przedstawiona w wyżej wymienionej pracy koncepcja stosunku Doncowa do Polski często jest przywoływana w literaturze i nieraz bywa uznawana za reprezentatywną dla całokształtu jego myśli. Nie powinno budzić to szczególnego zdziwienia, albowiem Pidstawy naszoji polityky należy uznać obok Nacjonalizmu i wydanej w 1944 r. pracy Duch naszoji dawnyny za najważniejszą książkę Doncowa ${ }^{22}$.

Niemniej trudno uznać opinię wyrażoną w pracy, będącą swoistym mostem pomiędzy okresami socjaldemokratycznym i nacjonalistycznym w myśli Doncowa, za reprezentatywną dla tego ostatniego, tym bardziej że już opinie przedstawione w 1923 r. na łamach „Zahrawy” stoją z nią w rażącej sprzeczności²3. Również publicystyka Doncowa drukowana na łamach „Literaturno-Naukowego Wistnyka” w latach 1922-1932 potwierdza stopniowe odchodzenie autora od orientacji polo-

18 Ibidem, s. 205-206.

19 Ibidem, s. 207.

20 Ibidem, s. 208.

21 Д. Донцов, Підстави нашої політики, Відень 1921, s. 97.

22 Idem, Націоналізм, Львів 1926; idem, Дух нашої давнини, Прага 1944.

23 Р „Заграва” 1923 nr 9, s. 139-141; Д.Д., Британська нота і Европейський схід, „Заграва”, 1923, nr 11, s. 161-164; Д.Д., Дві тактики, „Заграва” 1923, nr 11, s. 164; Д.Д., 3 приводу одної сенсацї, „Заграва”, 1923, nr 17, s. 278. 
nofilskich i coraz przychylniejsze spoglądanie w kierunku Niemiec Weimarskich ${ }^{24}$. Pomimo wyrażanych jeszcze w tym okresie pozytywnych opinii pod adresem sanacji i Józefa Piłsudskiego, stosunek Doncowa wobec Polski w tym okresie był już co najwyżej ambiwalentny ${ }^{25}$. Wydaje się, że niebagatelne znaczenie na ewolucję poglądów Doncowa w tym zakresie miała decyzja Rady Ambasadorów z 15 marca 1923 r. przyznająca Galicję Wschodnią Polsce, która rozwiała nadzieję na jakąkolwiek formę równoprawnej współpracy pomiędzy Polakami a Ukraińcami.

Publicystyka Doncowa ukazująca się na łamach „Wistnyka” w latach 1933-1939 stanowi dalszy ciąg tej ewolucji. Stosunek autora wobec Polski należy uznać za niechętny, a w niektórych aspektach nawet wrogi ${ }^{26}$. Towarzyszy temu coraz bardziej otwarcie wyrażana opcja germanofilska połączona $\mathrm{z}$ nieskrywanym podziwem Doncowa dla narodowego socjalizmu i Adolfa Hitlera. Problematyka ta najpełniej, nie tylko na łamach „Wistnyka”, ale w całym okresie międzywojennym, została zaprezentowana w maju 1934 r. w artykule Czy to Zachód...? (Czy Zachid...?), który wydaje się bez porównania bardziej istotny dla zrozumienia stosunku Doncowa wobec Polski, aniżeli Pidstawy naszoji polityky. Publikacja ta powstawała w specyficznym klimacie politycznym, określanym przez zmiany zachodzące wówczas w Europie. Niewątpliwie najważniejszą spośród nich było przejęcie władzy przez nazistów w Niemczech. Fakt ten Doncow oceniał jednoznacznie pozytywnie, widząc w ruchu nazistowskim wielki potencjał życiowy narodu niemieckiego ${ }^{27}$. Zauważalna w latach 1933-1934 w publicystyce Doncowa opcja pronazistowska koresponduje ze wzrostem częstotliwości pojawiania się tekstów o wymowie antysowieckiej i antyrosyjskiej. Doncow spoglądał na Hitlera z nadzieją, ciesząc się, że wreszcie znalazł się w Europie ktoś, kto zdecydował się „postąpić z bolszewikami po bolszewicku”28. W kwestii stosunków wewnętrznych w Rosji ukraiński myśliciel z jednej strony dostrzegał pełne aktywizmu i przepojone wolą tradycje rewolucji rosyjskiej, z drugiej konstatował postępujący upadek Związku Sowieckiego. W tekście Kinec rossijskoj rewoljucijii przekonywał wręcz, że faktyczna likwidacja znaczenia Rosji (na wzór chiński) zagrożonej przez Niemcy i Włochy na zachodzie oraz Japonię na wschodzie jest jak najbardziej możliwa ${ }^{29}$. Jedyne siły twórcze w Rosji Doncow dostrzegał w młodszym pokoleniu, co wszakże nie przekładało się na aparat partyjny ${ }^{30}$. Nasileniu się tematyki antyrosyjskiej w politycznym pisarstwie Doncowa w mniej-

24 Д.Д., Під знаком конфедерації, „Літературно-Науковий Вістник”, 1923, nr 8, s. 61-65; Д.Д., По Льокарні, „Літературно-Науковий Вістник”, 1925, nr 11, s. 265-271; Д.Д., Від Пілсьудского до Скшинського, „Літературно-Науковий Вістник”, 1926, nr 1, s. 69-73; Д. Донцов, Роман Дмовський - епігон евразійства, „Літературно-Науковий Вістник”, 1931, nr 9, s. 814-826.

25 Д.Д., Проблема поколінь, „Літературно-Науковий Вістник” 1928, nr 7-8, s. 318-328.

26 Д.Д., Перспективи, „Вістник”, 1936, nr 5, s. 456-469.

27 Д. Донцов, Кінець російської революції, „Вістник” 1933, nr 5, s. 378.

28 Ідет, Сумерк марксизму (Тардє - Гітлер - Сталінська опозиція, - i ми), „Вістник” 1933, nr 4, s. 304.

29 Іеет, Кінець російської революиії, s. 382.

30 Idem, Совітська молодь і ми, „Вістник” 1933, nr 1, s. 23. 
szym stopniu towarzyszyło ponowne podjęcie wątków antysemickich, wcześniej poruszanych podczas procesu zabójcy Petlury Szolema Szwarcbarda ${ }^{31}$.

Inny kontekst istotny dla omawianego tekstu stanowi zbliżenie polsko-sowieckie zapoczątkowane 25 lipca 1932 r. zawarciem polsko-sowieckiego paktu o nieagresji, a przejawiające się w daleko posuniętej intensyfikacji kontaktów. Mowa tutaj zarówno o zbliżeniu politycznym, jak i, przede wszystkim, o wzmożeniu relacji kulturalnych. Nasilenie kontaktów politycznych przejawiało się poprzez wymianę wizyt dygnitarzy politycznych (Karola Radka w Warszawie, Bogusława Miedzińskiego w Moskwie), zmianę wzajemnej oceny w prasie, a zwłaszcza wspólne wystąpienie Polski i Związku Sowieckiego przeciwko Paktowi Czterech ${ }^{32}$. Dla omawianego zagadnienia ważniejszy wydaje się kontekst kulturalny. Skala oddziaływania kultury sowieckiej w Polsce osiągnęła apogeum w 1933 r., przewyższając swoją intensywnością wymianę kulturalną z jakimkolwiek innym państwem (włączając w to Francję, do której tradycyjnie ciążyły polskie elity intelektualne). Szczególne znaczenie posiadało pojawienie się licznych przekładów literatury sowieckiej na język polski. W październiku $1933 \mathrm{r}$. ukazał się nawet specjalny numer „Wiadomości Literackich” na temat kultury sowieckiej. W odpowiedzi połowa objętości moskiewskiego tygodnika „Sowietskoje isskustwo" poświęcona została kulturze polskiej. Rozwijała się współpraca w zakresie teatru, filmu, muzyki ${ }^{33}$. Nie da się ukryć, że taka sytuacja musiała ówcześnie nastawiać Doncowa niechętnie wobec II Rzeczypospolitej.

Mając to na uwadze, należy jednakże zachować świadomość, iż ukraiński myśliciel, pomimo daleko posuniętego dogmatyzmu, był zdolny zaakceptować niektóre posunięcia liczących się graczy politycznych, które uderzały w sprawę ukraińską w imię ciągłości współpracy mogącej przynieść strategiczne korzyści. Świadczyć o tym może zarówno wyżej wzmiankowane stanowisko Doncowa wobec Polski w kwestii Galicji Wschodniej i Wołynia wyłożone w Pidstawach naszoj poliltyky, jak i artykuły ukraińskiego publicysty pisane po zajęciu Ukrainy Karpackiej przez Węgrów. Nawet faktyczne zezwolenie Hitlera na aneksję ukraińskiego parapaństwa, będące dodatkowo czytelnym i pozytywnym sygnałem Berlina pod adresem Moskwy, nie odwiodło Doncowa od proniemieckiej linii ${ }^{34}$. Pokazuje to, że chociaż zmiana w postrzeganiu Polski, która zaszła w 1934 r. na kanwie poprzedzających ją wydarzeń, jest warta podkreślenia, to jednak tekst Czy to Zachód...? można uznać bez popełnienia wielkiego błędu za reprezentatywny dla zobrazowania stosunku Doncowa wobec Polski w okresie 1923-1939 r., a nie tylko będący wyrazem aktualnego klimatu politycznego.

Stopniowe odejście od stanowiska propolskiego zostało już zaznaczone wcześniej, z kolei artykuły Doncowa poruszające zagadnienia polskie, publikowane w „Wistnyku” po 1934 r., utrzymane są dokładnie w tym samym duchu, co tekst

31 Idem, Буря над Заходом, „Вістник” 1934, nr 3, s. 226.

32 Por. W. Materski, Tarcza Europy. Stosunki polsko-sowieckie 1918-1939, Warszawa 1994, s. 261-269.

33 Ibidem, s. 272-275.

34 Д. Д., Березень 1939, „Вістник” 1939, nr 4, s. 299-300; Д. Д., Загадка III-ої імрерії „Вістник” 1939, nr 5, s. 339. 
Czy to Zachód...?. Polska nie jest w nich zaliczana, w odróżnieniu od Niemiec czy Włoch, do prawdziwego Zachodu czy też prawdziwej Europy. Śmierć Marszałka Piłsudskiego, jednego z niewielu polskich polityków ocenianego w swoim czasie pozytywnie przez Doncowa, musiała ostatecznie wpłynąć na porzucenie jakichkolwiek śladów orientacji propolskiej przez ukraińskiego publicystę. Doncow oskarżał idee polityczne w Polsce o posiadanie wyłącznie obronnego charakteru, a polskie koncepcje rozwiązania kwestii ukraińskiej oceniał jako tworzone „ad maiorem Moscovie gloriam"35. Taka interpretacja prowadziła do krytyki współpracy UNDO z oficjalnymi czynnikami polskimi ${ }^{36}$.

Zdając sobie sprawę z wagi i znaczenia tej problematyki, udostępniamy Państwu opracowany tekst Czy to Zachód...??37. Jesteśmy jednocześnie przekonani, że jego lektura pozwoli na lepsze zrozumienie stosunku Doncowa wobec Polski - stosunku niechętnego, ale odmiennego od mitów, jakie ciągle panują na ten temat w polskim dyskursie.

35 Д.Д., Перспективи, s. 463; Д. Донцов, Відень і Київ, 1938, nr 4, s. 287.

36 Д. Донцов, Між молотом і ковалом, 1938, nr 5, s. 377.

37 Artykuł został co prawda przetłumaczony jeszcze w dwudziestoleciu międzywojennym i ukazał się w „Buncie Młodych”. Materiał ten, nie jest wszakże dziś najłatwiej osiągalny, w Bibliotece Narodowej jest dostępny jedynie na mikrofilmie, z kolei w Bibliotece Jagiellońskiej brakuje odpowiedniego numeru, por. D. Doncow, Czy Zachód? List do Ukraińców o polskiej kulturze, „Bunt Młodych”, 1934, nr 12-13, s. 1-2. 


\section{Dm. Doncow}

Czy to Zachód...? ?38

Zachód mobilizuje się. Przeciwko październikowej „rewolucji”, przeciwko Tołstojowi i Dostojewskiemu, przeciwko „mesjaszowi” narodów. I jeszcze przeciwko jego satelicie, który przed 1934 laty przybił swojego mesjasza do krzyża.

Za rany - rany i krew za krew, jak śpiewa się w „Warszawiance”, można by rzec: za Sołówki - obozy koncentracyjne dla Torglerów ${ }^{39}$, za spalone biblioteki w Moskwie - stosy z marksistowskiej makulatury w Berlinie. Nowa Francja apeluje do geniusza rasy łacińskiej przeciwko wszystkiemu, co „wrogie naszemu duchowi narodowemu”, przeciwko cudzym ideom, które torują drogę cudzej inwazji. Przeciwko chaosowi ze wschodu jedni przywołują die Rasse ${ }^{40}$, drudzy - latinitét ${ }^{41}$, „niemiecką głębię" i „francuską jasność”.

Przez różne „Ligi Ochrony Praw Człowieka”, przez loże masońskie, przez prasę, kino przetacza się ta trucizna ze wschodu tocząc i podkopując filary, na których rozwinęła się kultura okcydentu.

Rywalizacja żelatyny $\mathrm{z}$ formą, tyranii chaosu z dyscypliną, moralnej mizerii $\mathrm{z}$ duchowym hartem.

Ukraina jest jednym $\mathrm{z}$ głównych terenów tych zmagań. Ale przerażająco niewielu $\mathrm{z}$ nas zdaje sobie sprawę $\mathrm{z}$ tego, że tylko na Zachodzie wykuwana jest broń przeciwko tyranii chaosu. Niektórzy nawet nie rozumieją przeciwieństwa Rosja Europa. Dlatego dyskusja z nimi na temat Europy jest tak jałowa. Jako prawowierni drahomanowcy ${ }^{42}$, nie znają ani idei wschodnich, ani zachodnich, a jedynie „ogólnoludzkie”. Dlatego Tołstoja mają za „wielkiego Europejczyka”, dlatego małpując format europejskich czasopism, myślą, że przejmują formę myśli europejskiej, dlatego „Nouvelles Litteraires” mylą z „Wiadomościami Literackimi”. Najtragiczniejszy z problemów współczesności dla nich po prostu nie istnieje. Obiektywnie rzecz biorąc, są oni nosicielami antyeuropejskiego bakcyla, chociaż ich obłudny język bezustannie trajkocze o Europie.

Inni nie uznają Europy, bo jakoby należymy do niej tylko geograficznie. A w dziedzinie kultury - musimy i Moskwie figę pokazać i na zgniły zachód splunąć. Samowystarczalność! Nowy stepowy Rzym! Na miarę naszych sił! Pewnie, że na miarę naszych sił, ale których naszych? Hiszpania wydała Don Kichota i Pansę. Kto jest wyrazicielem hiszpańskiego charakteru narodowego? Pierwszy, drugi? Ich synteza? Nasza ziemia wydała i menażerię „Martwych Dusz” i postacie Szewczenki

38 Д. Донцов, Чи Захід...? „Вістник”, 1934, nr 5, s. 377-387.

39 Ernst Torgler (1893-1963) - niemiecki polityk, w latach 1929-1933 przewodniczący Komunistycznej Partii Niemiec (KPD). Oskarżony o podpalenie gmachu parlamentu w 1933 r., a następnie uniewinniony $\mathrm{z}$ braku dowodów.

40 Rasa (niem.)

41 Łacińskość (franc.)

42 Zwolennicy teorii jednego z największych ukraińskich teoretyków socjalizmu Mychajła Drahomanowa (1841-1895). 
i stefanykowych „Synów”. Orientalna inercja i zachodni aktywizm. Którą z tych „własnych” sił obrać za fundament?

Francuzi nie wyrzekli się dziedzictwa własnej swojej spuścizny kulturowej. W walce ze swoim wschodem, uparcie trzymają się granicznej linii, wyznaczonej jeszcze przez legiony Cezara i ich kulturę, którą uznają za własną. Skądże się bierze zarozumiałość naszych zwolenników samowystarczalności?

Oczywiście, „własne” pierwiastki w naszej kulturze są najważniejsze, ale są to pierwiastki europejskie, a nie „Scytów-dzikusów”, których żądza zdobyczy pędziła na Ukrainę tak samo w XI jak i w XX wieku.

Wśród cudzoziemców świadomość naszego „okcydentalizmu” była od dawna powszechna. Aż do XVIII wieku jej intensywny płomień ogarniał i nas. A jej echa wybrzmiewają później i u mohylanina Myhałewycza ${ }^{43}$, według którego „Europa (może) każdego dobra zwać się matką" (1742), i u Kulisza ${ }^{44}$, który w jednym kręgu ideowym umieszczał „księcia Bismarcka i Loyolę”, i u Chwylowego ${ }^{45}$, z tąże samą „psychologiczną Europą”. Jedynie opierając się na tych „własnych” pierwiastkach - przeciwstawimy się z sukcesem chaosowi, nosicielami którego są współcześni nomadowie.

Similo similibus curantur, klin, klinem wybijać.

Przeciwko agresywności - agresywność. Europa wypraw krzyżowych, Europa, która podbiła dla swojej rasy dwa kontynenty, a z dwóch innych uczyniła swoje satrapie; która wytworzyła własną mistykę - mistykę „białego człowieka”, „wyższej” rasy - tej Europie nie straszny żaden Mahomet. Ale - tylko tej. Jedynie Zachód odważnie wystąpił z tezą, że „siła jest czasem dobrą rzeczą, choćby wtedy, kiedy tejże sile się przeciwstawia”... Że jest ona „tajemniczo powiązana z życiem i nie można jej osądzać, nie osądzając samego życia... Że osądzać można jedynie jej nadużycie, ale i je można ujarzmić jedynie inną, przeciwległą siłą"46.

Tylko Zachód wytworzył kodeks życia, twardy i surowy wobec jakiejkolwiek pobłażliwości, stojący wiecznie na straży; kodeks, na którym połamał sobie zęby nie jeden Zbawiciel zza Uralu. Tego kodeksu twardych zasad i surowego systemu jeździli kiedyś uczyć się do Paryża kardynała Richelieu i do Genui nasi „żacy” z Kijowa i Wołynia, z najdalej wysuniętego zakątka okcydentu. Żeby wzmocnić europejskie pierwiastki w naszej kulturze, aby nie dać się rozpanoszyć w atmosferze pograni-

43 Sofronij Myhałewycz (data ur. niez. - po 1751) - student, a następnie wykładowca Akademii Mohylańskiej w Kijowie. W latach 1731-1732 wykładowca Akademii Słowiańsko-Grecko-Łacińskiej w Moskwie, archimandryta Chamaliji.

44 Pantalejmon Kulisz (1819-1897) - ukraiński pisarz, poeta, etnograf, folklorysta, członek Bractwa Cyryla i Metodego, autor pierwszej ukraińskiej powieści historycznej pt. Czorna Rada (1857).

45 Mykoła Chwylowyj (1893-1933) - ukraiński pisarz i krytyk literacki, w drugiej połowie lat dwudziestych rozpoczął pisanie pamfletów politycznych, takich jak Kamo hrjadesz?, Dumky proty tecziji, Apołohety pisaryzmu postulujących uniezależnienie się kultury ukraińskiej od dominującego wpływu kultury rosyjskiej. Utwory te wywołały szeroką dyskusję literacką, jednakże Chwylowyj był zmuszony złożyć publiczną samokrytykę. W 1933 r. w proteście przeciwko szykanom wobec ukraińskiej inteligencji twórczej popełnił samobójstwo.

46 L. Daudet, Les idées en armes, Paris 1933, s. 245. 
cza demoralizującym wpływom Wschodu. „Wewnętrzna karność”, „niewzruszone decyzje” i „zdyscyplinowana akcja” w taką lapidarną formułę ujmuje ten kodeks Clemenceau ${ }^{47}$.

Do tych samych źródeł powinniśmy powrócić również i dziś - i w tych samych celach. Żeby wzmocnić nasze mięśnie i wyostrzyć wzrok, żeby uzbroić się w te idées en armes $^{48}$, które wykuwa się tylko w krajach, gdzie postąpiła noga Rzymu ${ }^{49}$.

Wspomniałem, że nasi drahomanowcy nie są nawet w stanie pojąć zasadniczego przeciwieństwa pomiędzy okcydentem i Wschodem. Inni przeciwstawiają Europie „stepowy Rzym” - Kijów. Wreszcie są i trzeci. Uznają oni przeciwieństwo, tylko nie są pewni, gdzie szukać tej Europy, na której mamy się oprzeć.

Tutaj dochodzę do tematu tego artykułu. Ci trzeci, szukając Europy, odnajdują ją we współczesnej Polsce. Czy mają słuszność? Czy można w kulturze tego okcydentu szukać ratunku? Ktoś może myśleć, że „Z narodów, które należą lub należały do imperium rosyjskiego, tylko Polacy i Ukraińcy mają do spełnienia wyraźnie określone funkcje w rozwiązaniu wstrząsających światem problemów”. Czy aby na pewno? Bez wątpienia kraj, który przyjął swoją kulturę wraz z katolicyzmem rzymskim jest krajem kultury zachodniej. Ale czy jest krajem tegoż wojującego Zachodu? Czy idee, którymi teraz żyje - są tymi idées en armes, za pomocą których Zachód chroni swoje oblicze przed destruktywnymi wpływami ze Wschodu?

W „Orgii” ${ }^{50}$ Kasandra mówi o Mojrze:

„jej prawica ciężka i twarda

ona wykuwa z narodów broń świata”

Taką „bronią świata” był Rzym. „Ciężka i twarda ręka” Mojry uczyniła z Francji Napoleona broń nowego świata, narzędzie zespołu nowych, wielkich idei, taran przeciwko innym. I tylko ten naród będzie źródłem wiecznego odnowienia dla innych - którym w ten sposób zaopiekowała się nieprzebłagana, ale łaskawa dla swoich wybrańców Mojra. To miał na uwadze i Mickiewicz, kiedy mówił „narody wtedy tylko... mają prawo do życia, kiedy wysługują się całemu rodowi ludzkiemu podtrzymaniem, albo obroną jakiejś wielkiej myśli albo wielkiego uczucia”. Czy dzisiejsza polska kultura jest przepełniona jakąś „wielką myślą”, „wielkim uczuciem”, takimi, jakimi była przepełniona wtedy, gdy Mickiewicz pisał swoje słowa?

Dwie wielkie idee stały u kolebki historycznej Polski: ecclesia militans ${ }^{51}$ i opanowanie Wschodu Europy. Idee nieprzychylne wobec nas, ale idee tego samego rodzaju, co i idea pruskich krzyżowców albo hiszpańskich zdobywców Ameryki. Były to idee szeroko zakrojone, idee, które podkreślały swoje zasadnicze przeciwieństwo wobec Wschodu, brały na ramiona wielki ciężar, na jedną kartę stawiały swe istnienie, powo-

47 G. Clemenceau, Demosthene, Paris 1926, s. 32.

48 Uzbrojone idee (franc.)

49 L. Daudet, op. cit., s. 245.

50 Utwór autorstwa Łesi Ukrainki.

51 Kościół wojujący (łac.). 
dowane „doniosłym trudem” historycznego przeznaczenia. W swoim czasie stanowiły natchnienie dla całej polskiej kultury, całej mistyki polskiej kultury. Koniec XVIII, a w zasadzie połowa XVII wieku zadały tym ideom wielki cios, chociaż ich nie zabiły. Uderzenia te były początkiem rusyfikacji, zmiany psychiki polskiej warstwy przywódczej, w kierunku jej „odeuropeizowania”. Już Custine ${ }^{52}$ zauważył, że nie zważając na politykę religijnego i politycznego ucisku, jaką prowadziła w Polsce Rosja, Polacy odnosili się do niej z mniejszą niechęcią, aniżeli do Niemców. Odnosząc się do słowiańskiego „pokrewieństwa” obydwu narodów dodaje - „nie wszyscy bracia kochają się wzajemnie, ale rozumieją się... Kiedy narody te rozdziela polityczna nienawiść, wówczas sama natura je ze sobą jedna, im samym na przekór. Kiedy polityka przestanie zmuszać jeden do gnębienia drugiego, lepiej poznają się ze sobą i pokochają" $\left.{ }^{53}\right)$... $\mathrm{Za}$ tym proroctwem kryje się o wiele głębsze spostrzeżenie dotyczące polskiej psychiki: zanik poczucia zasadniczości polsko-moskiewskiego konfliktu, zanik tej idei „przedmurza Europy”, któremu charakterystyczny wyraz dał później Dmowski; ten zanik zasadniczej wrogości obu kultur, którego np. nie ma ani śladu w francusko-niemieckim konflikcie, gdzie „polityczna nienawiść” jest głębszej i silniejszej natury...

W duchu zacierania tejże zasadniczości wychowywało się i popowstaniowe polskie pokolenie w Kongresówce. Marian Zdziechowski pisze: „zaczynałem gimnazjum (rosyjskie) z wyniesioną z domu niechęcią, prawie odrazą do języka rosyjskiego i literatury: kończąc byłem w literaturze tej rozkochany”. Równocześnie „budziły się sympatie do rosyjskiej społeczności", a ruch rewolucyjny w Rosji - wywołał w Kongresówce „rewolucyjne moskwofilstwo”. Zamiast wiary w Europę - rodziła się wiara w „młodą Rosję”, która była tą samą starą, tylko odwróconą na lewą stronę. Mówiąc dalej o Dmowskim i narodowo-demokratycznej orientacji podczas wojny, Zdziechowski zauważa: „,rozumiem, że można było uważać triumf Rosji za mniejsze zło, ale fascynacji mniejszym złem ja nie mogłem zrozumieć" $\left.{ }^{34}\right)$...

To była ta fascynacja (tak dobrze znana i nam), która powoli wytwarzała w społeczeństwie postawę antyeuropejską nadszarpując panującą niegdyś w Polsce ideę religijnego, politycznego i kulturowego opanowania Wschodu; ideę, która stawiała „polskość” w kręgu antagonizmów - nie lokalnych, lecz tych wielkich, których nosicielami byli Cromwell, Wallenstein, Gustaw Adolf i nie dawała jej ulec prowincjonalizacji.

To prawda, że tę ideę posłannictwa podnieśli jeszcze Mickiewicz, Krasiński, Prus, Sienkiewicz. Ale - już zniekształconą. „Polska - Mesjasz pośród narodów”, zapewne to także był mesjanizm, ale już pasywny.

Organ dzisiejszych młodych - „Młodzi” ${ }^{55}$, trochę pobłażliwie nazywa ten mesjanizm mesjanizmem „cierpiętników”, niegodnym „narodu-przewodnika”. Jednakże

52 Markiz Astolphe-Louis-Léonor de Custine (1790-1857) - francuski pisarz i podróżnik. Sławę przyniosła mu książka Listy $z$ Rosji opisująca rzeczywistość caratu za czasów Mikołaja I.

53 Маркіз де Кюстін, Росія в 1839 p., list 14 і 29.

54 M. Zdziechowski, Pod wrażeniem „Dziejów” M. Bobrzyńskiego, „Przegląd Współczesny” 1932, nr 1-2, s. 174-190.

55 Miesięcznik poświęcony sprawom młodzieży ukazujący się od 1926 r. w Krakowie. 
w pracach wymienionych wyżej autorów brzmi echo starej melodii - zasadniczego antagonizmu dwóch światów - pogarda do Moskala, jako do niższej „azjatyckiej” rasy, poczucie własnej wyższości kulturalnej. Spadkobiercy wspomnianych autorów o tej melodii zasadniczo zapominają. Błyskotliwa pod względem literackim epopeja Sienkiewicza, która niedawno wzbudziła burzliwą dyskusję, jest znamienna dla jawnego upadku wielkiej romantyki jagiellońskiej. „Ogniem i mieczem” bowiem, to już nie ta porywająca, świeża, wiosenno-burzliwa romantyka mickiewiczowskiego „roku 1812”, epopeja „dwunastu języków” Europy, które szły ogniem i mieczem na podbój Wschodu. Utwór Sienkiewicza, mimo jego barwności i siły ekspresji, posiada węższy horyzont - bo i konflikt, o którym jest tam mowa, jakbyśmy na niego nie patrzyli, w oczach autora i jego rodaków - stał się konfliktem lokalnym („wojna domowa")... Kiedy powiedzą, że winna temu rosyjska cenzura, dlaczegóż zatem ta cenzura nie powstrzymała Żeromskiego przed wydaniem za granicą swojej „Róży” pod pseudonimem Józefa Katerli?

Nie chcę powiedzieć, że „Róża” ma większy rozmach. Na odwrót, i ona, jak i cała twórczość Żeromskiego, posiada wielkie ślady tego duchowego „odeuropeizowania”, o którym wspomina Zdziechowski. W „Róży”, podobnie jak w „Tamtym” Zapolskiej, wielki konflikt historyczny maleje, zawęża się, sprowadza się do konfliktu nie dwóch światów, a dwóch systemów politycznych. Bo nienawiść do carskiego reżimu, która z nich bije, nie wykluczała - jak widzimy ze wspomnień Zdziechowskiego - ani miłości do „młodej Rosji”, ani do jej literatury i kultury... Jeszcze węższym staje się konflikt w błyskotliwie stylistycznie ujętej „Pożodze” Kossak-Szczuckiej, gdzie wielki historyczny antagonizm sprowadza się do antagonizmu o czysto społeczno-publicznym charakterze. Zresztą wszystkie te wymienione prace Żeromskiego (Katerli), Zapolskiej i Szczuckiej jawnie tchną tym „,cierpiętnictwem”, tak dalekim nawet od pewnego siebie aktywizmu i zaczepności Sienkiewicza, $\mathrm{z}$ bezkompromisową pogardą Jaremy do „tałatajstwa”...

Gdy czytam o detronizowaniu tegoż Jaremy Wiśniowieckiego przez pewną część polskiej prasy; kiedy czytam jak konserwatywni autorzy wyrzekają się walki z bolszewicką kulturą; jak hr. Łos ${ }^{56}$ wywleka na światło dzienne starą, skompromitowaną, na wskroś antyeuropejską ideę słowianofilstwa, widzę w tym kurczenie się i zanik tej romantyki, która nadawała polskiemu mesjanizmowi charakter spokrewnionych z nim europejskich idei.

Gdy czytam, jak w specjalnym Posłaniu biskupów wyrażana jest pochwała dla „dobrosąsiedzkich relacji” z krajem bezbożności, jak w tych relacjach widzi się „utrwalenie europejskiego pokoju" - tak jakby cmentarna cisza i pokój były najważniejszymi zadaniami, do jakich spieszy ecclesia militans, kiedy czytam jak K. Czapiński ${ }^{57}$ cieszy się z przyjaznych relacji z ZSRR i żąda, żeby były one „szczere” i żeby w GPU

56 Jan Nepomucen Bonifacy Łoś (1860-1928) - polski slawista profesor filologii słowiańskiej na Uniwersytecie Jagiellońskim. W latach 1923-1924 rektor tegoż.

57 Kazimierz Czapiński (1882-1941) - polski polityk, jeden z czołowych działaczy PPS poseł na Sejm Ustawodawczy oraz I i II kadencji. 
nie wynikały „jakiekolwiek wątpliwości wobec tej szczerości” („Naprzód”58, nr. 33) - tak jakby poparcie dla nowego więzienia narodów było pierwszorzędnym zadaniem socjalizmu - widzę w tym wszystkim całkowity zanik zdolności myślenia kategoriami szerszymi niż kategorie narodu prowincjonalnego.

To zacieśnienie horyzontu, ta rezygnacja z misji o historycznej doniosłości dla całego świata prowadzi również do przekreślenia przeszłości: nowa, ograniczona rzeczywistość przystosowuje historię do swoich nowych potrzeb, przykrawa zbyt obszerny kontusz przodków... Górka ${ }^{59}$ zarzuca błędy dawnej „kresowej polityce” Jagiellonów udowadniając im post factum, że powinni byli powstrzymać swoją ekspansję, a z Siedmiogrodu, Mołdawii i kozackiej Ukrainy uczynić państwa buforowe, przedmurze, ale „nie świata chrześcijańskiego, lecz Polski”... Polska powinna była sprowadzić swój konflikt ze Wschodem, konflikt dwóch światów, do roli sporu o granicę, do konfliktu Danii z Niemcami o Szlezwik albo belgijsko-niemieckiego o Eupen i Malmedy. Jakże to dalekie od mickiewiczowskiego „posługiwania całemu rodzajowi ludzkiemu”, od „popierania lub obrony jakiegoś wielkiego poglądu albo wielkiego uczucia" - charakterystycznych dla czołowych europejskich narodów!

Nie wylewam tutaj łez nad wspomnianym faktem (co byłoby dziwne w ustach Ukraińca), stwierdzam jedynie fakt. - Fakt rezygnacji z jednej z tych „uzbrojonych idei" w polskim piśmiennictwie, którymi silna jest Europa, z pomocą których ratowała i ratuje się przed zalewem wrogiej cywilizacji Wschodu, i z powodu których Europa ta w oczach narodów zniewolonych przez Wschód (jak nasz) jest „matką wszelkiego dobra", do której należy iść po naukę...

Nie dość powiedzieć, że mamy tu do czynienia z porzuceniem jednej z „uzbrojonych idei” okcydentu, z zanikiem dynamizmu polskiej kultury. Trzeba powiedzieć więcej: ta kultura nie tylko porzuca agresję przeciwko kulturze Wschodu, ale i sama ulega jego wpływom. Zauważyć można te wpływy u Żeromskiego w Przedwiośniu, a i wcześniej już w Dziejach grzechu, gdzie autor popada w zniewolenie (choć to jedynie epizod) hulacko-sybirskiej romantyki rosyjskiej. Całkowitą kapitulację przed rosyjskim Wschodem widzimy u Dmowskiego, z jego fascynacją „szerokością rosyjskiej duszy”, „zmysłem państwotwórczym” narodu rosyjskiego, jego przestrzeniami, duszą i „piękną literaturą”... To już znamienna oznaka tego zatrucia, o jakim wspomina Zdziechowski i które jest nam tak dobrze znane. Zatrucie to w naszych czasach, po odzyskaniu politycznej niepodległości, przebiega, jak przewidział to sto lat temu Custine - crescendo60: jest Strug ${ }^{61} \mathrm{z}$ jego „Mogiłą nieznanego żołnierza”, jest Choynowski ${ }^{62}$ („Młodość, miłość, awantura”).

58 Krakowski dziennik o orientacji socjalistycznej. Organ PPS.

59 Olgierd Górka (1887-1955) - polski historyk, profesor Uniwersytetu Lwowskiego, specjalista w zakresie stosunków pomiędzy Polską a krajami Europy Południowo-Wschodniej.

60 Narastając (wł.).

61 Tadeusz Gałecki (1873-1937) ps. Andrzej Strug - polski powieściopisarz i działacz socjalistyczny.

62 Piotr Choynowski (1885-1935) - polski prozaik i tłumacz. Specjalizował się w nowelach, nawiązywał do twórczości Sienkiewicza. 
Jak słusznie zauważa polska prasa, „w odróżnieniu od literatury rosyjskiej, (Babel „Armia konna”), literatura polska nie stworzyła pomników artystycznych wojny polsko-rosyjskiej $1920 \mathrm{r}^{\text {"”63 }}$

A dalej ma miejsce po prostu propaganda rosyjskiego Zbawiciela; naiwne, dziecięce opiewanie Lenina u Ossendowskiego ${ }^{64}$, rosyjskie inscenizacje i puszkinada Tuwima, „wielkie perspektywy” nowej kultury rosyjskiej, odkryte przez Otmara ${ }^{65}$, Radkowie i ich katolicko-żydowscy satelici w „Wiadomościach Literackich”, Rosjanin Ławrentjew ${ }^{66}$, który w tych samych „Wiadomościach” nakłada polskim czytelnikom bolszewickie okulary dla zupełnego zohydzenia tego wielkiego protestu przeciwko truciźnie Wschodu, jaki zaczął się na Place de la Concorde w Paryżu, w lutym tego roku. Dalej jest propaganda Boya-Żeleńskiego, tak nam znana z czasów Arcybaszewa ${ }^{67}$, pierwszej rewolucji i różnych Lig Wolnej Miłości; następnie głoszenie zamaskowanej pornografii, hałaśliwy i naiwny radykalizm (sympatie do „młodej Rosji”!), lansowanie nowych programów zapożyczonych z bolszewizmu, „Kurier Wileński” ${ }^{68}$, który głosi, że utrzymanie się religii chrześcijańskiej leży „jedynie w interesie międzynarodowej reakcji”, „Sygnały” ${ }^{69} \mathrm{i}$ „Kamena”70 z wyrazami solidarności dla wiedeńskich przyjaciół Stalina, cała powódź sztuk, sowieckich filmów i artykułów z ZSRS i o ZSRS nakierowanych na jeden cel: podkopanie wszelkich instytucji kultury europejskiej, cała tandeta gorkowsko-leninowsko-bakuninowskiej „cywilizacji”... To już nie karykatura zachodnich agresywnych idei, jaką był pasywny mesjanizm „narodu męczennika”, nie zawężenie tej idei do opozycji wobec starej Rosji reżimu carskiego (Żeromski, Zapolska), nie ta czy inna koniunkturalna orientacja, to właśnie ta „fascynacja mniejszym złem” (którego nawet już nie uważa się za zło), której nie mógł zrozumieć Zdziechowski, i która wdziera się przez tysiące otworów do psychiki inteligenckiej elity. Kilka

63 „Kurier Lwowski”, 1934, 16 IV.

64 Ferdynand Ossendowski (1876-1945) - polski pisarz, dziennikarz podróżnik i antykomunista. Jego fabularyzowana biografia Lenina paradoksalnie zawiera niezwykle ostrą krytykę rewolucji i komunizmu.

65 Jan Stanisław Berson ps. Otmar (1903-1946) - polski dziennikarz i publicysta „Gazety Polskiej” i „Głosu Prawdy”. W latach 1932-1935 był korespondentem Polskiej Agencji Telegraficznej w Moskwie. Pobyt ten zaowocował licznymi tekstami dotyczącymi Rosji Sowieckiej, które cieszyły się dużą popularnością, choć nie brakowało głosów krytycznych (m.in. Jerzy Niezbrzycki ps. Ryszard Wraga).

66 Pomyłka w zapisie nazwiska. Chodzi o rosyjskiego pisarza i dramaturga Borysa Ławrenjowa (1891-1959), który w relacjonował na łamach „Wiadomości Literackich” (nr 11, 1934) swoje wrażenia $\mathrm{z}$ wydarzeń w Paryżu związanymi z aferą Stawiskiego.

67 Michaił Arcybaszew (1878-1927) - rosyjski pisarz, dramaturg i publicysta. W swojej twórczości propagował idee wolnej miłości i swobody moralnej, które to kilkukrotnie zaprowadziły go na ławę sądową. Po przewrocie październikowym zajął negatywne stanowisko wobec bolszewików i w 1923 r. emigrował do Polski.

68 Dziennik wychodzący w Wilnie od 1924 r. posiadający charakter prasy polityczno-społecznej. $\mathrm{Z}$ początku bezpartyjny, następnie wspierał politykę Józefa Piłsudskiego.

69 Pismo ukazujące się we Lwowie w latach 1933-1934 oraz 1936-1939 o orientacji demokratycznej.

70 Pismo literackie ukazujące się w Chełmie Lubelskim w latach 1933-1939. 
wyjątków (Mackiewicz, „Słowo” wileńskie”71, „Bunt Młodych”72, antyBoy-owcy) potwierdza regułę.

Polska elita - publicystyka, poezja, proza - zajmuje się generalną rewizją całej swojej dotychczasowej koncepcji kultury, likwidacją testamentów historii, odwraca się „twarzą do wschodu”, jedną za drugą odrzuca te „idées en armes”, bez których Europa nie jest Europą, bez których nie ma skutecznej obrony przed trującymi gazami z Eurazji. Pojawiły się programy, ale mistyka znikła.

Nie uszło to uwagi Wschodu, komiwojażer rosyjsko-żydowskiego mesjanizmu, Ilja Erenburg ${ }^{73}$, jeszcze przed paktem ${ }^{74}$, tak z sympatią pisał o swoich nadwiślańskich kolegach-pisarzach: „w porównaniu z Niemcem, Anglikiem, a tym bardziej Francuzem, Polak jest dla nas bardziej zrozumiały. Jak nam (nam, czyli komu Żydom czy Moskalom? - D.D.), tak i jemu brak jest tego zachodniego wyrachowania i egoizmu, łatwo się on unosi, lekko popada w skrajności, jest marzycielem, szybko się rozkrochmala. Nasze największe nieszczęście - inercja jest również nieszczęściem Polaka. Rosyjska gościnność, miłość i zaciekawienie cudzoziemcami, niestałość, bezsenne noce, niekończące się spory, oddanie idei, naiwna wiara w siłę słowa, wszystko to łatwo można znaleźć nad brzegami Wisły”. W ogóle, „między Rosjaninem i Polakiem nie istnieją żadne duchowe formy odpychania”... I konkludując: „,W tym leży klucz hegemonii literatury rosyjskiej”75. Czy coś podobnego można byłoby przeczytać w tych czasach, kiedy Puszkin pisał swoje „Oszczercom Rosji”? Wtedy polska kultura rozwijała się (albo raczej konserwowała się) w granicach państwa rosyjskiego, teraz swobodnie poza nim. Ale wtedy sami Rosjanie uważali ją za przednią straż kultury europejskiej. Teraz, przyjazny Erenburg radośnie sytuuje ją po tamtej stronie barykady, stronie bronionej przez Puszkinów i Sobelshonów ${ }^{76}$. „Zachodnie wyrachowanie i egoizm”, brak „marzycielstwa” i „naiwnej wiary w siłę słów", brak zaufania do cudzoziemców et dona ferentes - cóż to jak nie ów moralny hart Europy, który do szaleństwa doprowadza wszystkich nawracających „zgniły Zachód”. „Wiara w siłę słowa”, „miłość do cudzoziemca” i prędkie „rozkrochmalenie”, cóż to, jak nie owe słowiańskie cechy, które ułatwiły spadkobiercom moskiewskich chanów z niemiecko-żydowsko-gruzińskim sztabem - ujarzmienie pod swoim berłem narodu rosyjskiego, Ukrainy i części Azji?

To „rozkrochmalenie” i brak odporności Erenburg konstatuje również u zachodnich sąsiadów. Siła drobnych, codziennych faktów, nie pozwala tak łatwo obalić jego

71 Właściwie „Słowo”, dziennik będący organem prasowym konserwatystów wileńskich wychodzący w Wilnie w latach 1922-1939.

72 Dwutygodnik społeczno-polityczny ukazujący się od 1931 r. pod redakcją Jerzego Giedroyca. W 1937 pismo zmieniło nazwę na „Polityka”.

73 Ilja Erenburg (1891-1967) - rosyjski pisarz, publicysta i poeta, zwolennik bolszewizmu, autor licznych powieści o tematyce filozoficzno-satyrycznej oraz społeczno-obyczajowej.

74 Chodzi o polsko-sowiecki pakt o nieagresji z 25 lipca 1932 r.

75 I. Ehrenburg, Visum der Zeit, Leipzig 1929.

76 Właściwe nazwisko jednego z wpływowych w swoim czasie polityków bolszewickich Karola Radka. 
twierdzenia i udowodnić, że nie ma on racji. Jedno z polskich czasopism porównuje dwa utwory wojenne - Anglika Sheriffa ${ }^{77}$ - Kres wędrówki i Moskala Bułhakowa Dni Turbinów: ludzie ci (u Bułhakowa) mogą nas śmieszyć, może wywołają na czyichś ustach wzgardliwy uśmiech, „nie potrafią nam tak zaimponować jak angielscy oficerowie u Sheriffa, ale są bardziej ludzcy, bardziej przyciągający, sympatyczniejsi, niż tamci, którzy w każdym calu są nieskazitelnymi dżentelmenami"78... To już zatrucie psychiki, to beznadziejny wschód: nie podziw dla tego, który z zaciśniętymi zębami znosi ból, a współczucie wobec tego, kto publicznie i bezwstydnie wywraca na lewą stronę swoje serce; współczucie nie dla aktywnego, a dla pasywnego, ideał „skrzywdzonych i poniżonych” - przeciwko ideałowi dżentelmena, Wschód przeciwko Zachodowi. Jakże inaczej podchodzi do tej sprawy Europejczyk! Custine opisuje scenę pobicia dorożkarza przez feldjegera. Drugi dorożkarz w tym czasie trzymał konia feldjegera.

Najpierw markiza oburzyła ohydna scena, ale - pisze - „krzyk (ofiary) zmniejszał moje współczucie”. Widział przed sobą już „tylko bydło...”. Czym głośniej ten człowiek krzyczał, tym twardszym stawało się moje serce, o tyle prawdziwe jest, że przedmioty naszego współczucia muszą zachować poczucie własnej godności, żebyśmy mogli rzeczywiście byli cierpieć razem z nimi. Współczucie to pewne połączenie z kimś, a któż... może łączyć się z tym, kim pogardza"? ${ }^{79}$ )

Prawda, jaką dziwną i cudowną muzyką dźwięczą te słowa, muzyką, jaka przypomina Mérimée ${ }^{80}$, Barbey d'Aurevilly ${ }^{81}$, muzyką całkowicie niezrozumiałą dla ludzi wschodu, zdolnych tylko do płaczu nad wartą pogardy ofiarą, albo też do trzymania katowskiego konia, obydwie czynności są pozbawione poczucia własnej godności... I jak ta sentencja francuskiego markiza rażąco odbiega od erenburgowsko-moskiewskiego ideału, który, jak widzimy, wdziera się już na najbliższy Zachód...

A oto jeszcze jedna podobna opinia, aby pokazać, że moralny rozkład, że opozycja przeciwko twardemu kodeksowi dżentelmena, wypływa od obu erenburgowskich "nas” - i od Moskali i od Żydów... Żydowska „Chwila”"2 też mówi o przepaści, jaka dzieli ją od „kamiennych oblicz Anglików”, ich „hartowanej” woli, stłumionych namiętności i pielęgnowania tych wszystkich cech dżentelmena, których suma znajduje wyraz w potędze imperium brytyjskiego" ${ }^{83}$, które trzeba ośmieszyć, poniżyć i zniszczyć, aby w chaosie wzajemnego bratania, pochłonąć i rozbroić moralnie Zachód, obezwładnić i oddać na pastwę mesjaszom ze Wschodu.

77 Robert Cedric Sheriff (1896-1975) - pisarz angielski znany głównie z powieści Kres Wędrówki, w której opisał własne doświadczenia z czasów pierwszej wojny światowej.

78 „Kurier Lwowski” 1931, 21 V.

79 Маркіз де Кюстін, op. cit., лист 17.

80 Prosper Mérimée (1803-1870) - francuski dramaturg, historyk, archeolog, tłumacz literatury rosyjskiej. Był członkiem Akademii Francuskiej.

81 Jules Amédée Barbey d’Aurevilly (1808-1889) - francuski pisarz, poeta, publicysta i krytyk literacki. W swojej twórczości nawiązywał do motywów fantastyki i satanizmu. Uchodził za teoretyka dandyzmu i prekursora dekadentyzmu.

82 Gazeta żydowska ukazująca się we Lwowie w latach 1919-1939.

83 „Хвіля”, 1930, 13 IX. 
Ciekawy proces, zauważony przez francuskiego podróżnika, siedem lat po powstaniu listopadowym, rozwija się dalej. Stępienie antywschodniego nastawienia elity narodowej, likwidacja mesjanizmu kulturalnego, duchowa asymilacja $\mathrm{z}$ owym wschodem, powolne rozpuszczenie niegdyś twardych pierwiastków okcydentalnych, a w najlepszym razie - neutralność w konflikcie dwóch cywilizacji, zwątpienie we własną europejską wyższość kulturalną, niekiedy wiara $\mathrm{w}$ wyższość cudzą, rewizja idei zachodnioeuropejskiego antemurale, sprowadzenie zasadniczego niegdyś antagonizmu do sporu dwóch sąsiadów, których dzielą słupy graniczne, a nie formy cywilizacji, pewien defetyzm, zamiana ,uzbrojonych idei" na gwarancje i syntezy.

Nie znaczy to, że z każdym wojowniczym Zachodem, nawet gdyby był contra nos byłoby nam po drodze. Ale nawet zasada ab hoste discimus ${ }^{84} \mathrm{w}$ danym wypadku nie ma zastosowania. Jedynie w XVI w. obrońcy prawosławia poszukiwali strawy duchowej w „łacińskiej” nauce w Polsce. Ale nie u Dmowskiego, skamieniałego w niemej fascynacji przed moskiewskim diabłem, nie w „Wiadomościach Literackich” z Radkiem, Tuwimem, Erenburgiem i Ławrentjewem, co niedawno wywołali „okrzyk obrzydzenia" we francuskiej prasie, nie w otmarowej korespondencji na temat $e x$ oriente $l u x^{85}$, nie w tej atmosferze moralnego osłabienia i duchowej kapitulacji mamy szukać dla siebie pokrzepienia.

Tego wszystkiego trzeba szukać gdzie indziej - u samych źródeł cywilizacji zachodniej. Tam, gdzie żyje świadomość zasadniczego przeciwieństwa wobec wschodu i konieczności walki z nim. Tam, gdzie żyli, albo żyją i nauczają, Karl Nötzel ${ }^{86}$ i de Vogüé ${ }^{87} \mathrm{z}$ ich miażdżącą krytyką kultury rosyjskiej Karl Leuthner ${ }^{88} \mathrm{z}$ aktem oskarżenia „przeciwko imperializmowi narodu rosyjskiego”, Jean Cassou ${ }^{89}$ - autor ,infamii” L. Tołstoja, Galahad ${ }^{90}$ - znienawidzony przez naszych ukraińskich i „,russkich” moskwofilów - z jego surową satyrą na zafascynowanych Wschodem „idiotów”, Saroléa ${ }^{11}$

84 Uczymy się od wrogów (łac.).

85 Światło ze wschodu (łac.).

86 Karl Nötzel (1870-1945) - niemiecko-rosyjski pisarz i filozof społeczny. Znany głównie jako tłumacz na język niemiecki dzieł licznych pisarzy rosyjskich m.in. Dostojewskiego, Tołstoja, Mikołaja Leskowa, Mikołaja Gogola, Włodzimierza Sołowiowa.

87 Eugène-Melchior vicomte de Vogüé (1848-1910) - francuski dyplomata, orientalista, krytyk literacki, historyk literatury oraz autor. Na przełomie lat siedemdziesiątych i osiemdziesiątych pełnił funkcję sekretarza ambasady francuskiej w Petersburgu.

88 Karl Leuthner (1869-1944) - austriacki polityk i dziennikarz, prawnik z wykształcenia. Związany z prawicowym odłamem socjaldemokracji. Autor pracy Rosyjski imperializm narodowy (1915).

89 Jean Cassou (1897-1986) - francuski pisarz i krytyk literacki, w trakcie wojny uczestnik ruchu oporu, po jej zakończeniu dyrektor Musée National d’art Moderne w Paryżu.

90 Bertha Eckstein Diener, ps. ser Galahad (1874-1948) - austriacka pisarka, dziennikarka podróżnicza i historyczka feminizmu. Autorka wydanej w 1925 r. książki pt. Przewodnik dla idiotów po rosyjskiej kulturze.

91 Charles Saroléa (1870-1953) - belgijski naukowiec i publicysta. Długoletni wykładowca filologii francuskiej na Uniwersytecie w Edynburgu. W latach 1912-1917 wydawał magazyn literacki „Everyman”, na łamach którego bronił doktryny dystrybucjonizmu. 
i Istrati ${ }^{92}$ - z pełnymi pasji filipikami przeciwko wschodniej gangrenie, Bourget ${ }^{93}-$ z filozoficznym kodeksem cywilizacji europejskiej, Massis ${ }^{94}-\mathrm{z}$ „obroną okcydentu”, gen. Castelnau ${ }^{95}$ - z nieprzebłaganą walką z masonerią i wschodnim żydostwem, Sorel ${ }^{96}$ i Daudet ${ }^{97}$ - z kultem tej zawziętości i siły, którą przeciwstawiają oni rozkładowym doktrynom Moskwy, wreszcie - pogromcy czerwonego carosławia nad Tybrem i nad Szprewą.

Szukać moralnego oparcia należy tam, gdzie można je znaleźć, tam, na tym Zachodzie, gdzie zrozumieli, że zza oblicza twórcy Soni i Aloszy, tak samo jak i twórcy „międzynarodowego braterstwa proletariatu” - wyziera szatańska gęba nieprzebłaganego rosyjskiego Katona z jego wiecznym ceterum censeo ${ }^{98}$ : o zrujnowaniu okcydentalnej Kartaginy.

Naszej lumpenburżuazji (jest nie tylko lumpenproletariat - jest i lumpenburżuazja), tej, co każdej minuty gotowa jest zdradzić swój stan, tej, która szachrajstwem - jak Stawiski ${ }^{99}$, chce wybić się na duchowych przewodników narodu albo na wielkich pisarzy; tej, która przystosowuje się do wszystkiego, która karmi mózg czytelników eklektyczną sołamachą ${ }^{100}$ pozbawioną zasad; tej, która gotowa kapitulować przed każdą siłą, nachalnej i tchórzliwej, bez steru i bez myśli - cierpnie skóra na samo wspomnienie o zbuntowanym Zachodzie, który nareszcie odnalazł swój hart i swoich wodzów.

„Kamienne oblicze” Zachodu, który nie chce się demobilizować i który nie drży przed obliczem chaosu, wywołuje przerażenie u naszych kapitulantów. Mówią oni, że ten nowy Zachód i jego zwolennicy u nas - to bolszewizm à rebours, pokazuja tylko, że organicznie nie rozumieją nowej doby, która jeśli chce odeprzeć bolszewizm i jego „sprzymierzeńców”, musi dorównywać mu siłą.

92 Panait Istrati (1884-1935) - pisarz rumuński, debiutował na łamach prasy socjalistycznej.W 1916 wyjechał na leczenie do Szwajcarii, a stamtąd przeniósł się do Francji. Wszystkie najważniejsze powieści napisał w języku francuskim.

93 Paul Bourget (1852-1935) - francuski pisarz i eseista; przeciwnik naturalizmu, inicjator powrotu do literatury psychologicznej.

94 Henri Massis (1886-1970) - zwolennik Charlesa Maurrasa, twórca koncepcji obrony Zachodu (défense de l'Occident). W latach II wojny światowej zaangażowany w życie polityczne Francji Vichy.

95 Noël Marie Joseph Édouard, Vicomte de Curières de Castelnau (1851-1944) - generał francuski w latach I wojny światowej, jeden z propagatorów attaque à outrance, czyli działań ofensywnych za wszelką cenę. Po zakończeniu wojny polityk Bloku Narodowego (Bloc national).

96 Georges Sorel (1847-1922) - francuski socjolog, początkowo zwolennik syndykalizmu, po strajku generalnym we Francji w 1909 r. przeszedł na pozycje narodowego syndykalizmu oraz zbliżył się światopoglądowo do Akcji Francuskiej Charlesa Maurrasa.

97 Léon Daudet (1867-1942) - francuski pisarz i publicysta, syn słynnego pisarza Alphonsa Daudet, monarchista, współpracownik Akcji Francuskiej.

98 A poza tym sądzę (łac.).

99 Serge Alexandre Stavisky (1886-1934) - francuski oszust ukraińskiego pochodzenia. Wielokrotnie zatrzymywany przez francuską policję za nadużycia finansowe, szachrajstwo i handel narkotykami. Afera Stawiskiego, która wybuchła w związku z powiązaniami niektórych polityków z nadużyciami Stawiskiego doprowadziła do upadku rządu i próby przewrotu prawicowego.

100 Nazwa ukraińskiego dania narodowego. 
Zachód mobilizuje się. Zachód odzyskuje swoją agresywność. Zachód, o którym mówię, jeszcze nie wyczerpał się ideowo, wytwarza jasną, wykrystalizowaną myśl, jeszcze nie pozbył się swojej dynamiki. I, co najważniejsze, jest świadomy grożącego niebezpieczeństwa. Czego nie można powiedzieć o Zachodzie, który zamiast niebezpieczeństwa ze Wschodu - „obwieszcza” swoje pozdrowienie moskiewskim wysłannikom w Wiedniu. Tiutczew pisał, że - „między Europą i Rosją nie może być ani paktów ani pojednania. Życie jednej oznacza śmierć drugiej”. Świadomość tego, wiecznie żywa w Europie, teraz zaogniła się. Wrogowie nowej Europy powtarzają hasła o „nowym średniowieczu". Tak w odporze wobec rujnujących doktryn Wschodu Europa odnalazła swoje dawne oblicze, z jakim witała Maurów, Atyllę, Turków, ze stosem dla heretyków, z inkwizycją dla niedowiarków, z kołem dla renegatów, i z tym hartem, z całym kodeksem wartości, z tą karnością, które kiedyś natchnęły nową siłą i nasze stepy.

Wtedy, kiedy jako przednia straż tejże Europy stały w połowieckich stepach igorowe pułki, które szukały nie „szczęścia ludu pracującego”, choćby i z rąk baskaków, ale „honoru i sławy”; które walczyły nie o granicę, a o osłabienie i wyniszczenie ordy. Przegradzały one step nie tylko swoimi „czerwonymi tarczami”, lecz i tymi ideami, które wtedy w formie chrześcijaństwa wkładały im miecz do rąk. Były to prawdziwe „idées en armes”.

Na Zachodzie ich wówczas poszukiwano, na prawdziwym Zachodzie znajdziemy je i dzisiaj. Ad fontes!

\section{Dmytro Dontsov and Poland - two myths}

The paper presents Dmytro Dontsov's attitude, Ukrainian ideologue of integral nationalism, towards Poland based on the source essential for this issue, which is controversial nowadays. Some researchers recognize Dontsov's stand, included in a book titled Pidstawy Naszoji Polityky [Foundations of Our Politics, Vienna 1921], where he calls for entering an alliance with Poland and even opted for temporary resignation from Eastern Galicia, as representative. Dontsov also faces accusations that his ideology was supposed to prepare bases for genocide of the Polish population during war.

Dontsov's article titled Czy to Zachód?, printed in "Wistnyk" in Lviv in 1934, shows that none of the above mentioned attitudes correspond to the reality. On the one hand, Dontsov's attitudes to Poland showed reluctance, on the other hand, the Ukrainian thinker did not see Poland as the main enemy. In the article, Dontsov warns the Ukrainian community against Poland in view of the growing Russian influences on the Vistula River and the weakening the so-called "warlike" spirit of the West. Dontsov noticed the last elements in the "real" West among thinkers such as George Sorrel and Leon Daudet. According to Dontsov, fascist Italy as well as ethnic and Nazi Germany were supposed to fulfill them in their policies.

Translated by Marta Antoniuk

\section{Дмитро Донцов и Польша - два мифа}

Текст является попыткой взглянуть на отношение идеолога украинского интегрального национализма Дмитро (Дмитрия Ивановича) Донцова к Польше, опираясь на обработку 
показательного для этой проблематики источника. В настоящее время этот вопрос рождает споры. С одной стороны, часть исследователей принимает за основу позицию Донцова, содержащуюся в работе Підстави нашої політики (Вена 1921 г.), в которой он призывал к заключению Украиной союза с Польшей, и даже предлагал временно отречься от Восточной Галиции. Одновременно Донцов сталкивается с упреками, что его идеология должна была подготовить почву для геноцида польского населения, совершенного ОУН во время войны.

Как показывает статья Донцова Чи Захід?, опубликованная в 1934 г. на страницах львовского «Вістника», ни одна из вышеупомянутых точек зрения не отвечает действительности. С одной стороны, отношение Донцова к Польше отмечено было отчетливой неприязнью, с другой, однако, украинский мыслитель не относился к польскому государству как к главному врагу, которым он считал Россию. В исследуемом тексте Донцов предостерегает украинское общество от ориентации на Польшу ввиду усиления советского влияния над Вислой, а также ослабления там духа т. н. «воинственного запада». Эти последние элементы Донцов замечал на «истинном» западе среди мыслителей, таких как Жорж Сорель или Леон Доде. Государствами, которые должны были осуществлять их в своей политике, были, по мнению Донцова, фашистская Италия и национал-социалистическая Германия.

Перевод Агнешка Поспишьль

\section{Bibliografia}

Doncow D., Czy Zachód? List do Ukraińców o polskiej kulturze, „Bunt Młodych”, nr 12-13, s. 1-2. Łobodowski J., Dmytro Doncow. Życie i działalność, „Zeszyty Historyczne”, 1981, z. 55, nr 158-159.

Kulińska L., Działalność terrorystyczna i sabotażowa ukrainskich organizacji nacjonalistycznych w Polsce w latach 1922-1939, Kraków 2009.

Motyka G., Ukraińska partyzantka 1942-1960. Działalność Organizacji Ukraińskich Nacjonalistów i Ukraińskiej Powstańczej Armii, Warszawa 2006.

Materski W., Tarcza Europy. Stosunki polsko-sowieckie 1918-1939, Warszawa 1994.

Poliszczuk W., Doktryna Dmytra Doncowa. Tekst. Analiza, Toronto 2006.

Polska i Ukraina: rozmowy z Bohdanem Osadczukiem przeprowadzili B. Kerski i A. S. Kowalczyk, Wrocław 2008.

Stryjek T., Europejskość Dmytra Doncowa, czyli o cechach szczególnych ideologii ukraińskiego nacjonalizmu, [w:] Antypolska akcja OUN-UPA 1943-1944. Fakty i interpretacje, red. G. Motyka, D. Libionka, Warszawa 2002, s. 19-32.

Stryjek T., Ukraińska idea narodowa okresu międzywojennego, Toruń 2013 (wydanie drugie). Torzecki R., Kwestia ukrainska w Polsce w latach 1923-1929, Kraków 1989.

Wysocki R., Organizacja Ukraińskich Nacjonalistów w Polsce w latach 1929-1939, Lublin 2003.

Wysocki R., Źródło twórczej inspiracji czy wróg? Obraz Polski i stosunków polsko-ukraińskich w ujęciu Dmytra Doncowa, [w:] Primum vivere deinde philosophari. O ludziach czynu w dziejach Europy Srodkowej i Wschodniej. Księga jubileuszowa dedykowana Profesorowi Janowi Rzońcy z okazji siedemdziesiątych urodzin, red. M. Białokur, A. Szczepaniak, Opole-Toruń 2009, s. 203-217.

Ziemkiewicz R., Myśmy wszystko zapomnieli, http://www.rp.pl/artykul/125944.html [dostęp 26.04.2014].

Зайцев О., Украӥнський інтегральний націоналізм (1920-1930-ті роки). Нариси інтелектуальної історії, Київ 2013.

Лисяк Рудницкий I., Iсторичні есе, t. 2, Київ 1994.

[Д. Донсов] Д., На теми дня, „Заграва” 1923, nr 2, s. 17-19. 
[Д. Донсов] Д.Д., Березень 1939, „Вістник” 1939, nr 4, s. 298-305.

[Д. Донсов] Д.Д., Загадка III-ої імрерії, „Вістник” 1939, nr 5, s. 326-342.

[Д. Донсов] Д.Д., Від Пілсьудского до Скшинського, „Літературно-Науковий Вістник”, 1926, nr 1, s. 69-73.

[Д. Донсов] Д.Д., Британська нота і Европейський схід, „Заграва”,1923, nr 11, s. 161-164

[Д. Донсов] Д.Д., Дві тактики, „Заграва” 1923, nr 11, s. 164.

[Д. Донсов] Д.Д., 3 приводу одної сенсаиії, „Заграва” 1923, nr 17, s. 278.

[Д. Донсов] Д.Д., Перспективи, „Вістник” 1936, nr 5, s. 452-469.

[Д. Донсов] Д.Д., Під знаком конфедераціi, „Літературно-Науковий Вістник”, 1923, nr 8, s. 61-65.

[Д. Донсов] Д.Д., По Льокарні, „Літературно-Науковий Вістник”, 1925, nr 11.

[Д. Донсов] Д.Д, Проблема поколінь, „Літературно-Науковий Вістник” 1928, nr 7-8, s. 318-328.

Д. Донцов, Буря над Заходом, „Вістник” 1934, nr 3, s. 223-227.

Д. Донцов, Дух нашої давнини, Прага 1944.

Д. Донцов, Відень і Київ, 1938, nr 4, s. 281-287.

Д. Донцов, Кінець російської революиї, „Вістник” 1933, nr 5, s. 374-389.

Д. Донцов, Льозанський мир і Україна, „Заграва” 1923 nr 9, s. 139-141.

Д. Донцов, Між молотом і ковадлом, 1938, nr 5, s. 375-386.

Д. Донцов, Модерне москвофільство, Київ 1913.

Д. Донцов, Начіоналізм, Львів 1926.

Д. Донцов, Партія чи орден „Вістник” 1933, nr 2, s. 116-134.

Д.Донцов, Підстави нашої політики, Відень 1921.

Д. Донцов, Совітська молодь і ми, „Вістник” 1933, nr 1, s. 17-32.

Д. Донцов, Сумерк марксизму (Тардє - Гітлер - Сталінська опозиція, - $i$ ми), „Вістник” 1933, nr 4, s. 299-308.

Д. Донцов, Роман Дмовський - епігон евразійства, „Літературно-Науковий Вістник”, 1931, nr 9, s. 814-826.

Д. Донцов, Чи Захід...? „Вістник”, 1934, nr 5, s. 377-387.

Marek Wojnar - magister historii, doktorant w Zakładzie Historii Europy Wschodniej Instytutu Historii Uniwersytetu Jagiellońskiego. Przygotowuje pracę doktorską poświęconą roli koncepcji imperialnych i mocarstwowych w myśli ukraińskiego nacjonalizmu integralnego doby międzywojennej. Uczestniczy w realizowanym pod kierownictwem prof. Andrzeja Nowaka projekcie Fundacji na Rzecz Nauki Polskiej „Historie i pamięci imperiów w Europie Wschodniej - studia porównawcze". Interesuje się problematyką myśli politycznej oraz pamięci historycznej w Europie Wschodniej. Współpracuje z „Nową Europą Wschodnią”. 